\title{
Rhesus incompatibility in a four-day-old infant
}

\author{
AA Widnyana, MD; Retayasa, MD
}

$\mathrm{I}$ $\mathrm{n}$ Western countries, severe hemolytic disease of the newborn is most often due to rhesus (Rh) incompatibility. Most of the world's population is Rh-positive, mainly in Asia. However, Rhnegative can also be found around the world, and occurs mostly among the Baskanians and around the Mediterranean. ${ }^{1}$ The prevalence of Rh-negative people are as follows: Chinese and Japanese $<1 \%$, Indians 3-10\%, Indonesians $<0.5 \%$, Baskanians $30 \%$, Negroes 5\%, and Europeans 17\%. Among Caucasians, the prevalence is approximately $15 \%$. For every 1000 pregnancies in white women who are $\mathrm{Rh}$-negative, approximately 90 have $\mathrm{Rh}$-positive fetus. $^{2}$

Jaundice, anemia, and enlargement of the liver and spleen are clinical signs of the disease entity, known as hemolytic disease of the newborn. The condition starts in utero and affects the erythropoietic system of the fetus, often produces an appearance caused by circulating erythroblasts, originally named erythroblastosis fetalis. ${ }^{2,3}$ The most common cause of hemolytic diseases in fetus and newborn is blood group incompatibility. The antibody, originating from the maternal serum, enters the fetal circulation through the placenta and attaches to the antigen of the infant's red cell membrane subsequently causing destruction of the cells. The severity of the disease ranges from mild anemia to stillbirth, depending on the number of red cells destroyed and the ability of the fetus to compensate the increase in production of new cells. ${ }^{2,3}$

This paper reports the first case of Rh-incompatibility in newborns found at our hospital.

\section{Case report}

A four-day-old, balinese, male infant, was admitted to the Child Health Department at Sanglah Hospital, Denpasar on November 1, 2001 with a chief complaint of yellowish skin since four hours after birth.

There was no history of bleeding or traumatic delivery, no history of icterus in family members. There was no fever, vomiting, or convulsion. He was the third child of healthy Balinese parents, born spontaneously and vigorously.

On physical examination, his appearances were alert, anemic, and icteric. The respiratory rate was 30 /minute, regular, with a heart rate of 124 /minute, and the axillary temperature $37^{\circ} \mathrm{C}$. The body weight was 2700 grams, body length was $50 \mathrm{~cm}$. The heart and lungs were normal. The liver was enlarged $1 / 4$ $1 / 4$, and had a firm, flat border. Spleen was not palpable. Neurological examinations showed no abnormality.

Laboratory findings revealed hemoglobin level of $6.5 \mathrm{~g} / \mathrm{dL}$, hematocrit 23.0\%, Red Blood Cells (RBCs) level 2.37 millions/dL, reticulocytes 10.7\%, platelet count $196.000 / \mathrm{dL}$, and leukocyte count 10.800/dL. Serum albumin was $3.31 \mathrm{~g} / \mathrm{dL}$, bilirubin

From the Department of Child Health, Medical School, Udayana University, Sanglah Hospital, Denpasar, Bali, Indonesia.

Reprint requests to: AA Widnyana, MD, Department of Child Health, Sanglah Hospital, Jalan Nias, Denpasar, Bali, Indonesia. Tel. 62-361227911-15 ext. 128; Fax. 62-361-244038. 
direct was $24.89 \mathrm{mg} / \mathrm{dL}$, bilirubin total was $42.6 \mathrm{mg} /$ $\mathrm{dL}$, and blood glucose was $50 \mathrm{mg} / \mathrm{dL}$.

The infant was $\mathrm{O} R(\mathrm{D})$-positive, the mother was $\mathrm{O} R \mathrm{Rh}(\mathrm{D})$-negative and his father was $\mathrm{O} R \mathrm{Rh}(\mathrm{D})$ positive. Direct Coombs test of the infant as well as of the mother was positive. Indirect Coombs test of the mother was also positive with a titer of 1:523.

Based on clinical examination and laboratory findings, the diagnosis of $\mathrm{Rh}$ incompatibility was established. The patient was immediately treated with exchange transfusion using $\mathrm{O}$ Rh-negative whole blood and phototherapy.

On November 8, 2001 the infant appeared better and more active. He was discharged in good condition, with a body weight of 2950 grams, billirubin direct level of $4.4 \mathrm{mg} / \mathrm{dL}$, and billirubin indirect level of $6.0 \mathrm{mg} / \mathrm{dL}$.

\section{Discussion}

Variable severity of isoimmune hemolytic anemia of the newborn may result from $\mathrm{Rh}$ incompatibility between an Rh-negative mother, previously sensitized by the $R h(D)$ antigen, and Rh-positive fetus. The Rh system is composed of three basic pairs of antigens: Cc, Dd, and Ee. The presence of D determines whether an individual is Rh-positive. The $\mathrm{d}$ antigen, a reciprocal of $\mathrm{D}$, has not yet been discovered. However, the absence of $\mathrm{D}$ is known to result in $\mathrm{Rh}(\mathrm{D})$-negative. The $\mathrm{D}$ antigen is much more immunogenic than that of $\mathrm{C}, \mathrm{c}, \mathrm{E}, \mathrm{e}$; thus production of anti-D in $R h(D)$-negative women is the primary cause of hemolytic diseases in fetuses who are $\mathrm{Rh}(\mathrm{D})$-positive. As the $\mathrm{d}$ antigen has not yet been found, unfortunately, the zygosity for $\mathrm{D}$ of an $\mathrm{Rh}(\mathrm{D})$-positive person can only be established for certain by giving birth to a Rh-negative offspring. The zygosity of the father is of extreme importance, that if the father is homozygous for the $\mathrm{D}$ antigen (DD), all of his children will be $\mathrm{Rh}(\mathrm{D})$-positive and thus can be afflicted with Rh-hemolytic diseases if the mother is $R h(D)$-negative and produces anti-D antibody. In contrast, if the father is heterozygous for the $\mathrm{D}$ antigen (Dd), then only $50 \%$ of his children will be Rh(D)-positive and at risk for hemolytic diseases of the newborn. The onset of clinical diseases begins in utero as the result of active placental transfer of maternal immunoglobulin $G$ (IgG) Rh antibody. ${ }^{1-3}$

Maternal IgG antibodies to Rh(D) transfers via the placenta, covering and destroying the Rh(D)positive fetal red cells and initiating the chain of events that leads to death from hydrops in $25 \%$ of affected fetuses and from kernicterus in $25 \%$ of affected neonates.

Initial exposure of the mother to the $\mathrm{Rh}$ antigen occurs most often during parturition, miscarriage, abortion, and ectopic pregnancy. Recognition of the antigen by the immune system ensues after initial exposure, and reexposure to the $\mathrm{Rh}$ antigen will induce a maternal anamnestic response and elevation of specific IgG Rh antibody. ${ }^{1,3}$ This antibody will be transferred through the placenta and attaches to the Rh antigen sites of the fetal erythrocytes resulting in intravascular hemolysis of erythrocytes within the fetal liver and spleen. The rate of the hemolytic process is proportionate in part to the levels of the maternal antibody titer. However, it is more accurately reflected in the antepartum period by elevation of billirubin concentration in the amniotic fluid, and by the rise of unconjugated billirubin rate in the postpartum period. ${ }^{1-4}$ Compensatory reticulocytosis and the shortening of erythrocytes generation time may result in anemia in the newborn infant and a risk of multiple systemic complications if unable to match the often high rate of hemolysis in utero. ${ }^{2-4}$

The signs and symptoms of Rh incompatibility are specific. Its clinical presentation is the result of the degree of red cells destruction and of compensatory erythrocyte production in the fetus. In general, the more severe the anemia, the more severe the clinical manifestations and the higher the risk for central nervous system damage caused by hiperbilirubinemia. ${ }^{1-4,8}$

Jaundice, is the most common neonatal sign of Rh disease, which usually appears within the first 24 hours of life. Low cord-blood hemoglobin at birth reflects the relative severity of the hemolytic process in utero and is present in 50\% of cases. Hepatosplenomegaly is seen in severe hemolysis, occasionally occurring in relation with ascites, which may increase the risk of splenic rupture. ${ }^{6,7}$

Hydrops fetalis, is a severe $\mathrm{Rh}$ disease and has a historical association with it. Clinical features in 
the fetus include progressive hypoproteinemia with ascites or pleural effusion, or both severe and chronic anemia with secondary hypoxemia. There is an increased risk of late fetal death, stillbirth, and intolerance of active labor. ${ }^{3,5}$

Elevated reticulocytes level reflects the degree of compensation and also support the diagnosis of an ongoing hemolytic process. A strong, positive, direct Coombs test indicates that fetal RBCs are coated with antibodies which is diagnostic for $\mathrm{Rh}$ incompatibility. ${ }^{3,6}$ The findings of Rh-hemolytic disease in the newborn are identical to those of autoimmune hemolytic disease mediated by IgG antibody. Since hemolytic disease of the newborn is caused by antibody response in the mother, the best source of antibody is the maternal serum. $3,6,8$

The infant's blood group was $\mathrm{O} R \mathrm{Rh}(\mathrm{D})$-positive, his mother was $\mathrm{O} R h(\mathrm{D})$-negative, and his father was $\mathrm{O} R$ h(D)-positive. Direct Coombs test of the infant was positive, indirect and direct Coombs test of his mother were positive. His mother's titer of anti D antibody was 1:523. Based on these findings, the diagnosis of $\mathrm{Rh}$ incompatibility was established.

The problems of Rh-hemolytic diseases have been reduced by the introduction and routine administrations of $\mathrm{Rh}$ immune globulin to all unsensitized Rh-negative mothers who have delivered Rh-positive infant or who have had spontaneous or induced abortion. ${ }^{1-4,8}$

The accepted method of isosensitization to $\mathrm{Rh}(\mathrm{D})$ is the administration of $250-300 \mathrm{mg}$ of $\mathrm{Rh}$ immune globulin intramuscularly to all unsensitized Rh-negative women within 72 hours before delivery of an Rh-positive infant. ${ }^{1,3}$

Exchange transfusion remains a major and effective method in the management of hyperbilirubinemia in the severely affected newborn and of ameliorating neurotoxicity. The objectives of exchange transfusion are to remove antibody-coated red cells, which are a potentially lethal source of bilirubin, and replacing them with red cells compatible with that of the mother, and also to remove bilirubin and antibody able to combine with any new red cells produced by the infant. $1,3,8$

For exchange transfusion, we used fresh whole blood which was also Rh compatible with the mother. The volume of exchange transfusion is usually calculated at two times the blood volume of the in- fant, or about $160 \mathrm{ml} / \mathrm{kg}$. Since most of the effective removal of red cells occurs during the first $80 \mathrm{ml} / \mathrm{kg}$, the volume of exchange is limited to one unit of whole blood or less in small infants. A two time volume exchange replaces approximately $90 \%$ of the circulating red cells. ${ }^{1,8,11}$

Exchange transfusion is the prime therapeutic maneuver for significant hyperbilirubinemia resulting from immune hemolysis; however, the use of phototherapy has increased, particularly in mildly affected infants. 8,11

Phototherapy was introduced in order to prevent hyperbilirubinemia in premature infants. Its success in preventing nonimmunohemolytic hyperbilirubinemia and the resultant neurologic sequele has led to its widespread use as an accepted treatment for hyperbilirubinemia of different causes. Phototherapy has less immediate morbidity and mortality than that of exchange transfusion and much simpler. These factors are the basis for the use of phototherapy for hyperbilirubinemia in all immune hemolysis. ${ }^{3}, 8,11$

In our case, exchange transfusion was done with group $\mathrm{O} R$ h-negative fresh whole blood in the amount of $440 \mathrm{ml}$ and followed by phototherapy 12 hours/day because the infant suffered from hyperbilirubunemia, and anemia. The infant was discharged from the hospital after 7 days of hospitalization in good condition, with a body weight of 2950 grams and bilirubin direct level of $4.4 \mathrm{mg} / \mathrm{dL}$ and indirect level of $6.0 \mathrm{mg} / \mathrm{dL}$.

In summary, a four-day-old, Balinese, male infant, was admitted with the chief complaint of icterus since the first day of life, and was diagnosed of having hyperbiliru-binemia due to $\mathrm{Rh}$ incompatibility. Exchange transfusion and phototherapy were done. The patient was discharged in good condition.

\section{References}

1. Zenk KE. Rh Incompatibility. In: Gomella TL, editor. Neonatology management, procedures. 4th ed. St. Louis: McGraw-Hill Co; 1999. p. 326-30

2. Ballard RA. Hemolytic Anemia. In: Taeusch HW, editor. Avery's diseases of the newborn. 7th ed. St Louis: W. B. Saunders Co; 1998. p. 1087-91 
3. Stoll BJ, Kleigman RM. Hemolytic disease of the newborn due to rhesus incompatibility. In: Behrman RE, editor. Nelson's textbook of pediatrics. 14th ed. London: W. B. Saunders. Co; 1992.p. 483-5

4. Zipursky A. Isoimmune Hemolytic diseases. In: David G. Nathan, editors. Hematology of infancy and childhood. 3rd ed. Philadelphia: W. B. Saunders Co; 1987. p. 44-71

5. Mayne S. Rate of rhesus sensitization before and after implementation of a community based antenatal prophylaxis program. Br Med J 1997;315:1588

6. Van Dijk B. Preventing RhD haemolytic disease of the newborn. Br Med J 1997; 315:1480-3
7. Bowman JM. RhD hemolytic disease of the newborn. N Engl J Med 1998;339:1775-7

8. Luban NLC. Hemolytic disease of the newborn: Progenitor cells and late effects. N Engl J Med 1998;338:829-31

9. Wagle S, Prashant GD. Hemolytic diseases in newborn. Available from: URL: www.emedicine.com/ped/topic/ 959.htm.

10. Salem L. Rh Incompatibility. Available from: URL: www.emedicine.com/emerg/topic/507.htm.

11. Baehner RL. Hemolytic diseases of the newborn. In: Miller DR., editor. Blood diseases of infancy and childhood. 7 th ed. St Louis: Mosby; 1995. p. 253-65 